\title{
A new model of the upper mantle structure beneath the western rim of the East European Craton
}

\author{
M. Dec ${ }^{1}$, M. Malinowski ${ }^{1}$, and E. Perchuc ${ }^{2}$ \\ ${ }^{1}$ Institute of Geophysics, Polish Academy of Sciences, Ks. Janusza 64, 01-452 Warsaw, Poland \\ ${ }^{2}$ Bernardynska 21/57, 02-904 Warsaw, Poland \\ Correspondence to: M. Dec (monikadec@igf.edu.pl) and E. Perchuc (perchuc.ed.geo@gmail.com)
}

Received: 27 January 2014 - Published in Solid Earth Discuss.: 14 February 2014

Revised: 15 May 2014 - Accepted: 16 May 2014 - Published: 26 June 2014

\begin{abstract}
We present a new 1-D $P$ wave seismic velocity model (called MP1-SUW) of the upper mantle structure beneath the western rim of the East European Craton (EEC) based on the analysis of the earthquakes recorded at the Suwałki (SUW) seismic station located in NE Poland which belongs to the Polish Seismological Network (PLSN). Motivation for this study arises from the observation of a group of reflected waves after expected $P_{410} P$ at epicentral distances $2300-2800 \mathrm{~km}$ from the SUW station. Although the existing global models represent the first-arrival traveltimes, they do not represent the full wavefield with all reflected waves because they do not take into account the structural features occurring regionally such as $300 \mathrm{~km}$ discontinuity. We perform $P$ wave traveltime analysis using 1-D and 2-D forward ray-tracing modelling for the distances of up to $3000 \mathrm{~km}$. We analysed 249 natural seismic events from four azimuthal spans with epicentres in the western Mediterranean Sea region (WMSR), the Greece and Turkey region (GTR), the Caucasus region (CR) and the part of the northern MidAtlantic Ridge near the Jan Mayen Island (JMR). For all chosen regions, except the JMR group for which 2-D modelling was performed, we estimate a 1-D average velocity model which will characterize the main seismic discontinuities. It appears that a single 1-D model (MP1-SUW model) explains well the observed traveltimes for the analysed groups of events. Differences resulting from the different azimuth range of earthquakes are close to the assumed picking uncertainty. The MP1-SUW model documents the bottom of the asthenospheric low-velocity zone (LVZ) at the depth of $220 \mathrm{~km}, 335 \mathrm{~km}$ discontinuity and the zone with the reduction of $P$ wave velocity atop $410 \mathrm{~km}$ discontinuity which is depressed to $440 \mathrm{~km}$ depth. The nature of the regionally oc-
\end{abstract}

curring $300 \mathrm{~km}$ boundary is explained here by tracing the ancient subduction regime related to the closure of the Iapetus Ocean, the Rheic Ocean and the Tornquist Sea.

\section{Introduction}

One-dimensional reference models are employed almost in every seismological method aimed at imaging of Earth's interior (tomography, receiver functions, underside reflections). However, results of those methods can be biased by the choice of the background velocity model (e.g. Bastow, 2012). Therefore, in the regional studies, it might be more appropriate to use modified reference models taking into account, e.g. the tectonic regime of the area (e.g. Perchuc and Thybo, 1996). Following this strategy, we attempt to derive a onedimensional upper mantle $P$ wave velocity model for the areas surrounding the East European Craton (EEC) to the west and to the south. Toward this end, we use the data recorded at the Suwałki (SUW) station belonging to the Polish Seismological Network. The data recorded at the SUW station were used in few seismological studies (e.g. Bock et al., 1997; Świeczak et al., 2004; Wilde-Piórko, 2005), but none of these were focusing on the detailed interpretation of the recorded traveltimes in the far-regional mode.

Due to the advancement in instrumentation and access to infrastructure, array seismology is developing rapidly (e.g. the Earthscope USArray project; Levander, 2003). However, the cost of experiments remain very high. Here we would like to explore the concept of using single-station data from the existing seismological network to study the upper mantle structure based on the traveltimes and amplitudes of the 
a)

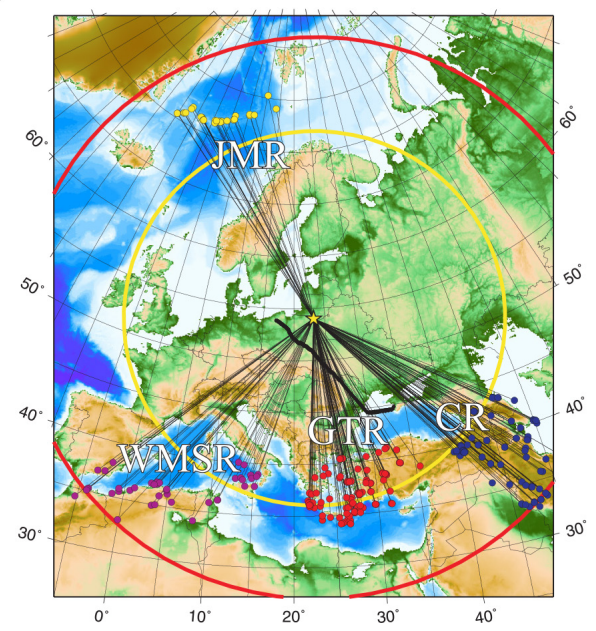

b)

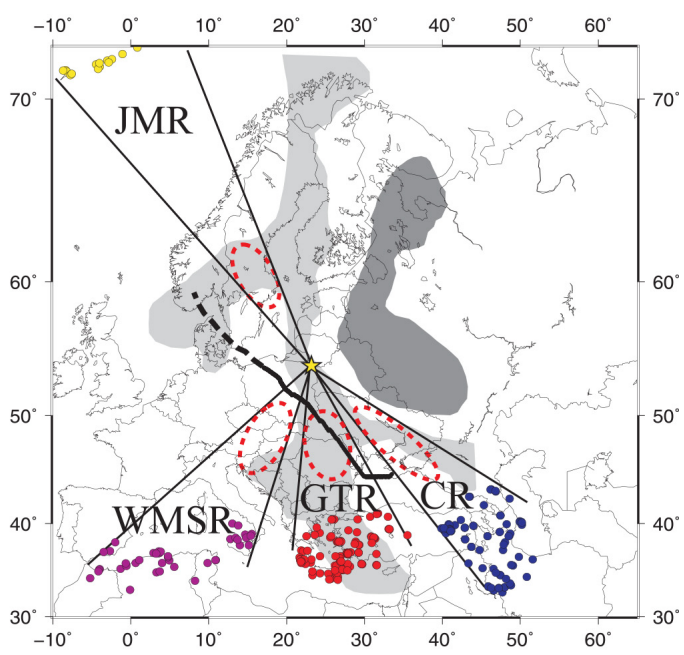

Figure 1. (a) Four groups of earthquakes recorded at the SUW station (yellow asterisk): JMR (yellow points), WMSR (violet points), GTR (red points) and CR (blue points). Circles centred at SUW mark the distance of 2000 (yellow) and $3000 \mathrm{~km}$ (red). Thick black line represents the TTZ. (b) Map of the study area with indication of the regions to which our upper mantle model pertains (red dashed ellipses). Areas shaded in grey are characterized by higher $S$ wave velocities at $250 \mathrm{~km}$ depth according to the model of Shapiro and Ritzwoller (2002). Light grey represents velocities about $4.65 \mathrm{~km} \mathrm{~s}^{-1}$ and dark grey about $4.80 \mathrm{~km} \mathrm{~s}^{-1}$.

body waves. The necessary prerequisite for performing such a study is the selection of the station that is located optimally for imaging particular mantle structure by providing proper azimuthal span and epicentral distances of the recorded earthquakes (see e.g. Nita et al., 2012).

The choice of the SUW station for this analysis is twofold. First of all, it is characterized by a good signal-to-noise ratio and relatively simple wavefield, as it is located on the stable part of the EEC with a thin sedimentary cover. Secondly, the earthquakes recorded from the four azimuthal sectors (northern Mid-Atlantic Ridge, Western Mediterranean Sea, Greece-Turkey, and Caucasus) are located in the 1500$3000 \mathrm{~km}$ epicentral distance range, providing proper illumination of the upper mantle structure between the base of the asthenosphere and the $410 \mathrm{~km}$ discontinuity. The bottoming points of the refracted waves and midpoints of the reflected waves fall in to the south-western rim of the East European Craton as indicated in Fig. 1. Therefore, we can study the influence of the Teisseyre-Tornquist zone (TTZ) on the recorded wavefield and mantle structure.

First, we present the tectonic setting and a review of the studies pertaining to the investigated area, which mainly focused on Earth's crust. Subsequently, we describe data (seismic waveforms from natural seismic events) and methods used in this analysis (1-D and 2-D ray-tracing modelling). In the results section we present all analysed seismic sections together with the traveltimes calculated for our preferred upper mantle model. It is followed by error analysis and traveltime residuals statistics. Finally, we discuss our results in the context of the geodynamics of the circum-EEC region.

\section{Tectonic setting and previous geophysical investigations}

In order to understand the structure and nature of the upper mantle below the Baltica, it is necessary to understand its history as a palaeocontinent which was moving across Iapetus Ocean with other palaeocontinents and microplates which are nowadays neighbouring Baltica. The EEC is the oldest part of eastern Europe. It formed about 1.8-1.7 Ga (years ago) as a result of a collision between three separate plates: Fenoscandia, Sarmatia and Volgo-Uralia (Bogdanova et al., 2001, Bogdanova et al., 2005). The history of the palaeoplate movements from Vendian to Permian was described by Cocks and Torsvik (2006). There were two major palaeotectonical events. First, about $450 \mathrm{Ma}$ in the Ordovician, Avalonia separated from Gondwana and docked with Baltica and afterwards they both joined Laurentia. The last event was connected with the closure of the Iapetus Ocean which ended about $420 \mathrm{Ma}$ and the closure of the Tornquist Sea - a branch of Iapetus. A different situation had place in the SW part of the cratonic rim. In this area there were Rheic Ocean structures formed from Devonian to Permian and then the Palaeotethyan, which were evolving up to the TTZ (Ziegler et al., 2006). Caledonian structures: Northwest Highlands (Gee, 1975) and Polish Caledonides (Znosko, 1986) were imposed on the NW and SW margins of the EEC.

Geophysical studies are mainly seismic. There were numerous deep seismic sounding profiles recorded both west and east of the TTZ (see recent summary in Guterch et al., 2010). Starting with the LT profiles located in Poland (Guterch et al., 1986), through the EUGENO-S project 
in Denmark and southern Sweden (EUGENO-S Working Group et al., 1988), Polish projects POLONAISE'97 (Guterch et al., 1999) and CELEBRATION 2000 (Guterch et al., 2001), the FENNOLORA transect (Guggisberg and Berthelsen, 1987; Abramovitz et al., 2002), the BABEL project (BABEL Working Group, 1991), the MONA LISA (Abramovitz et al., 1998) or EUROBRIDGE projects (EUROBRIDGE Seismic Working Group, 1999) we have a good control on the crustal structure of the EEC and surrounding areas.

All of these projects provided gross crustal structure down to the Moho and only in few cases were deeper boundaries interpreted (e.g. Grad et al., 2002). During the acquisition of the deep seismic sounding profiles, some upper mantle phases (both reflections and refractions) were traced in the offset range beyond $400 \mathrm{~km}$ (e.g. in project POLONAISE'97, Grad et al., 2002; EUGENO-S Working Group, 1988; BABEL Working Group, 1993; MONA LISA, Abramovitz et al., 1999). Apart from the controlled-source seismology, some passive-source experiments were conducted with the TOR project being the most significant (Gregersen et al., 2010; Plomerova et al., 2002). The TOR project spanning about $1000 \mathrm{~km}$ from northern Germany, through Denmark up to southern Sweden, crossed principal tectonic zones inside the rim of the EEC such as the Variscan Front, the Caledonian Deformation Front and the Sorgenfrei-Tornquist zone - the northern extension of the TTZ. This allowed us to image seismic structure of the crust and upper mantle (e.g. Somali et al., 2006, Gregersen et al., 2010). The recently conducted PASSEQ project (Wilde-Piórko et al., 2008) provided new data for studying mantle structure across the TTZ, e.g. using teleseismic $P$ wave receiver functions (Knapmeyer-Endrun et al., 2013).

\section{Data and method}

The SUW seismic station was chosen for this study because of the good recording conditions in the remote part of NE Poland and the thin sediment cover resulting in high-quality seismic signal registrations. The station is equipped with the STS-2 sensor and the data are recorded at $20 \mathrm{~Hz}$. We used broadband data recorded between 1997 and 2010 for earthquakes with magnitude greater than 4.5. The hypocentre locations were taken from the ISC bulletin (International Seismological Centre; http://www.isc.ac.uk/iscbulletin). The retrieved waveforms were converted from the native MSEED to SEG-Y format in order to make seismic record sections suitable for interpretation and modelling using standard tools used in controlled-source seismology (Zelt, 1994).

The 249 events analysed (see Supplement and Fig. 1) are located in the following areas:
Table 1. Mean signal-to-noise ratio for the analysed groups of events.

\begin{tabular}{lcccc}
\hline \multirow{2}{*}{ Region } & \multirow{2}{*}{$\begin{array}{c}\text { Number } \\
\text { of } \\
\text { events }\end{array}$} & $\begin{array}{c}\text { Raw } \\
\text { data }\end{array}$ & $\begin{array}{c}\text { After filtering } \\
(0.5-2.0 \mathrm{~Hz})\end{array}$ & $\begin{array}{c}\text { Improvement } \\
(\%)\end{array}$ \\
\hline JMR & 34 & 4.70 & 8.17 & 73.83 \\
CR 020 & 34 & 2.57 & 7.50 & 191.83 \\
CR 2050 & 23 & 3.52 & 6.66 & 89.20 \\
CR 50+ & 12 & 5.54 & 12.66 & 128.52 \\
GTR 020 & 53 & 6.59 & 4.85 & -26.40 \\
GTR 2050 & 36 & 3.61 & 5.26 & 45.71 \\
GTR 50+ & 14 & 13.84 & 18.02 & 30.20 \\
WMSR & 43 & 6.30 & 11.54 & 83.17 \\
Average & & 5.38 & 8.16 & 67.76 \\
\hline
\end{tabular}

1. rift zone around the Jan Mayen region in the northern Atlantic (JMR)

2. Western Mediterranean Sea region (WMSR)

3. Greece and Turkey region (GTR)

4. Caucasus region (CR).

All earthquakes generated in the JMR (part of the MidAtlantic Ridge) (Fig. 2a) were shallow crustal ones (depth down to $10 \mathrm{~km}$ ). The earthquakes in the WMSR were also shallow, with focal depths down to $20 \mathrm{~km}$ (Fig. 2b). However, the data from the GTR (Fig. 2c) and CR (Fig. 2d), due to a large variability of the source depths, were separated into three groups with the focal depth ranges: 0-20 km, 20-50 km and $>50 \mathrm{~km}$. We divided earthquakes into these focal depth ranges after evaluating differences in traveltimes calculated for different focal depths in the AK135 model (Kennett et al., 1995). Modelling was performed for each group separately. It allowed us to limit static shifts in the record sections to $1 \mathrm{~s}$. We did not apply focal depth corrections to the data belonging to each epicentral group.

Seismic record sections sorted according to the increasing epicentral distance consist of the following number of seismograms: 34 (JMR), 43 (WMR), 103 (GTR), 69 (CR). We tested a range of bandpass filter frequencies for displaying data and finally we concluded that the best results were obtained for a $0.5-2.0 \mathrm{~Hz}$ bandwidth. This bandpass filter is commonly used in analysing data recorded in the far-regional mode (e.g. Chu et al., 2012; Świeczak et al., 2004). As a data quality check we calculated the signal-to-noise (SNR) ratio, estimated using energy of the signal in the $2 \mathrm{~s}$ wide window before and after first arrivals. Calculations were made using the ZPLOT software (Zelt, 1994). Table 1 shows mean SNRs calculated for the individual group of events. Group of the deepest earthquakes from the GTR are characterized by the best SNR for raw data. The best improvement after filtering was observed for the CR group for events with focal depths between 0 and $20 \mathrm{~km}$. The average SNR for all raw data is 
a)

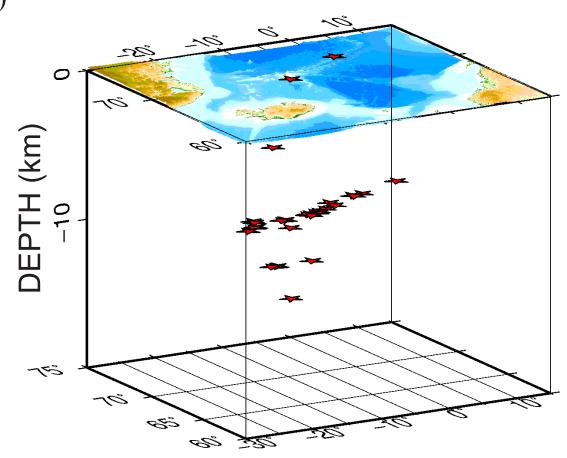

c)

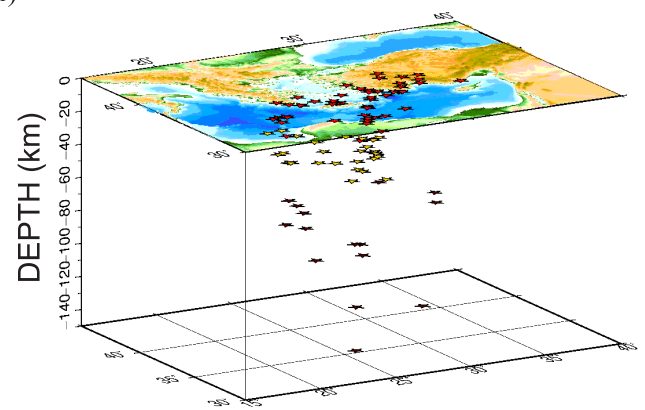

b)

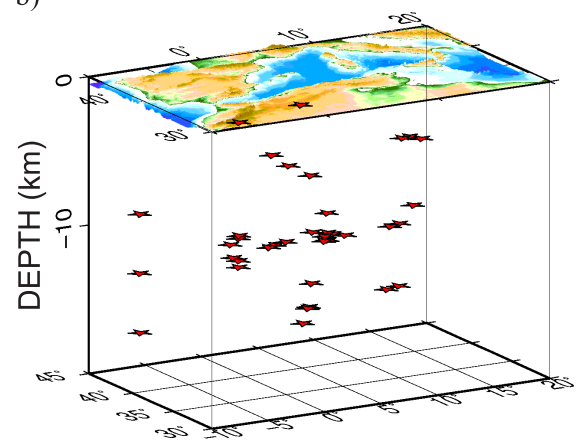

d)

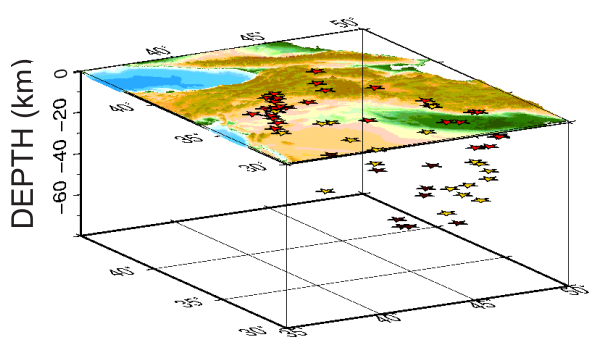

Figure 2. Distribution of the focal depths for the analysed groups of earthquakes: (a) JMR, (b) WMSR, (c) GTR, (d) CR.

Table 2. List of seismic events shown in Fig. 3. Numbers from column 1 correspond to numbers of seismic records in Fig. 3. (UTC coordinated universal time)

\begin{tabular}{|c|c|c|c|c|c|c|c|c|}
\hline No. & Offset $(\mathrm{km})$ & Date & Origin time (UTC) & Lat & Long & Depth $(\mathrm{km})$ & Mag (mb) & Seismic region \\
\hline 1 & 2259.18 & 24 Jun 2002 & 01:20:37.60 & 35.92 & 9.88 & 10.0 & 4.7 & Tunisia \\
\hline 2 & 2267.73 & 25 Feb 2007 & 21:53:13.80 & 73.18 & 6.77 & 10.0 & 5.1 & Greenland Sea \\
\hline 3 & 2275.16 & 07 Jun 1999 & $16: 10: 33.66$ & 73.02 & 5.35 & 10.0 & 5.2 & Greenland Sea \\
\hline 4 & 2307.27 & 30 Aug 2005 & 20:53:48.17 & 71.91 & -1.09 & 10.0 & 4.8 & Jan Mayen Island region \\
\hline 5 & 2322.30 & 08 Sep 2008 & $21: 17: 15.10$ & 72.63 & 0.96 & 10.0 & 5.0 & Norwegian Sea \\
\hline 6 & 2323.20 & 26 Aug 1999 & 05:03:05.04 & 71.70 & -2.43 & 10.0 & 5.1 & Jan Mayen Island region \\
\hline 7 & 2334.51 & 02 Dec 1997 & 00:02:03.51 & 71.65 & -3.03 & 10.0 & 5.0 & Jan Mayen Island region \\
\hline 8 & 2340.29 & 13 Aug 2006 & 19:03:08.50 & 71.39 & -4.00 & 13.1 & 4.8 & Jan Mayen Island region \\
\hline 9 & 2360.94 & 23 Mar 1998 & 20:19:27.74 & 71.50 & -4.47 & 10.0 & 5.1 & Jan Mayen Island region \\
\hline 10 & 2392.71 & 22 May 2003 & $13: 57: 21.27$ & 37.12 & 3.84 & 10.0 & 4.8 & Western Mediterranean Sea \\
\hline 11 & 2395.07 & 16 Nov 2000 & 11:33:08.87 & 36.63 & 4.79 & 8.7 & 4.8 & Northern Algeria \\
\hline 12 & 2402.14 & 22 May 2003 & 03:14:04.85 & 37.16 & 3.57 & 15.0 & 5.2 & Western Mediterranean Sea \\
\hline 13 & 2412.09 & 02 Sep 2008 & 20:00:50.82 & 38.72 & 45.79 & 3.0 & 4.9 & Iran-Armenia-Azerbaijan border \\
\hline 14 & 2421.17 & 19 Jun 2003 & $12: 59: 23.14$ & 71.08 & -7.64 & 0.5 & 5.6 & Jan Mayen Island region \\
\hline 15 & 2422.18 & 14 Apr 2004 & 23:07:37.81 & 71.05 & -7.74 & 10.5 & 5.7 & Jan Mayen Island region \\
\hline 16 & 2424.21 & 27 May 2003 & $17: 11: 28.35$ & 36.94 & 3.54 & 6.1 & 5.5 & Northern Algeria \\
\hline 17 & 2430.11 & 18 Aug 2000 & $18: 15: 06.54$ & 36.19 & 4.96 & 10.0 & 4.9 & Northern Algeria \\
\hline
\end{tabular}

5.38 and after bandpass filtering we achieve improvement of $\sim 68 \%$. Therefore, all presented seismic sections are displayed with a $0.5-2.0 \mathrm{~Hz}$ bandpass filter.

In this work we analysed earthquakes recorded in the far-regional mode, i.e. with epicentral distances of 1500 $3000 \mathrm{~km}$. As shown, for example, by Thybo and Perchuc (1997), this offset range allows one to study upper mantle structure between the Lehman discontinuity at ca. $200 \mathrm{~km}$ depth and the $410 \mathrm{~km}$ discontinuity. Phase identification was supported by aligning the observed reflectivity based on the maximum amplitude (Fig. 3) for earthquakes from different azimuthal spans (Table 2). Good alignment was obtained for the phase emerging at the time characteristic of the $410 \mathrm{~km}$ discontinuity (Fig. 3a). There are also some other 


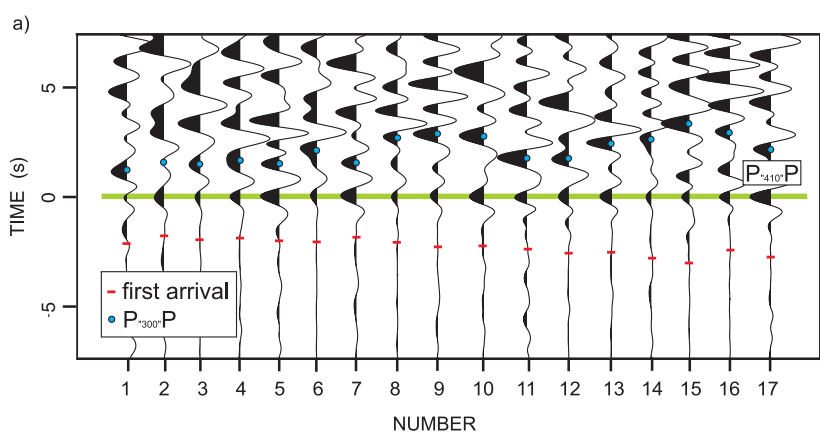

b)

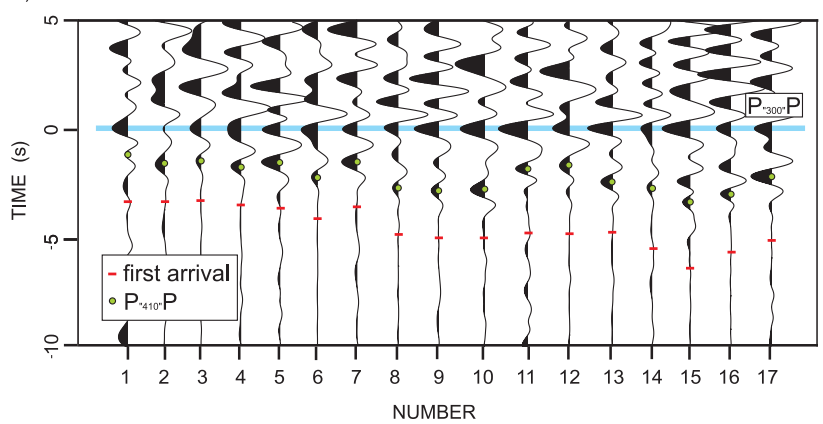

Figure 3. Seismograms aligned by the maximum amplitudes of (a) $P_{410} P$ (green line) and (b) $P_{300} P$ (blue line). Seismograms are ordered by the event's number (see Table 2). Red dashes represent first arrivals. Blue dots in (a) correspond to blue line in (b). Green dots in (b) correspond to green line in (a).

strong phases that can be aligned in the epicentral distance of $2260-2430 \mathrm{~km}$ (Fig. 3b), later interpreted as being the reflection phases from around $300 \mathrm{~km}$ depth. The discontinuity at ca. $300 \mathrm{~km}$ was introduced based on earlier results of Nita et al. (2012) and the presence of the reflected arrivals above the $P_{410} P$ reflected phase. The following reflected and refracted seismic phases were interpreted in the record sections (Figs. 4-7) during subsequent modelling: $P_{220}-$ refracted wave from the bottom of the asthenosphere (LVZ), $P_{335} P$ - reflected wave from the regionally occurring discontinuity located at the depth of about $335 \mathrm{~km}$, and $P_{440}$ and $P_{440} P-$ refracted and reflected waves from depressed $410 \mathrm{~km}$ discontinuity, modelled at ca. $440 \mathrm{~km}$ depth.

We used forward trial-and-error one-dimensional (Kamiński and Muller, 1979) or two-dimensional ray-tracing modelling (Gorman, 2002) in order to fit the observed traveltimes of the refracted and reflected $P$ wave mantle phases and derive upper mantle $P$ wave velocity models beneath the areas indicated in Fig. 1b. We use spherical earth conversion in 1-D modelling and spherical earth 2-D ray-tracing in case of 2-D modelling. We picked first arrivals $\left(P_{220}\right.$ and $\left.P_{440}\right)$ and reflected waves from discontinuities at the depths of 220,335 and $440 \mathrm{~km}\left(P_{220} P, P_{335} P\right.$ and $P_{440} P$ respectively). Finally, models were verified by calculating synthetic seismograms using the reflectivity method (Fuchs and Muller, 1971; Muller, 1985).

\section{Results}

We begin our modelling with the analysis of the MP-1 model derived for the seismically active part of the United States (Perchuc et al., 2008), west of the North American Craton. The North American Craton was created in the same time as the EEC (Hoffman, 1988) and is characterized by similar features, which justifies such an analysis. For all chosen regions in this analysis we try to estimate a 1-D average model which will characterize the main seismic discontinuities. It came out during the modelling that a single 1-D model (MP1SUW model) explains well the observed traveltimes for the four groups of events analysed. Differences resulting from the different azimuth range of earthquakes are close to the assumed picking uncertainty $(0.1 \mathrm{~s})$.

Figure 4 a shows the obtained velocity distribution beneath the western rim of the EEC (MP1-SUW model, Table 3) resulting from the forward ray-tracing modelling and fitting of the calculated traveltimes to the observed mantle arrivals (Figs. 4-7). Because of the far-regional offset range used in this study, the velocities in the crust and down to $8^{\circ}$ discontinuity (ca. $100 \mathrm{~km}$ depth; Thybo and Perchuc, 1997) and within the asthenosphere were introduced a priori and fixed during modelling. The crustal part of the models was based on the published deep seismic sounding results (e.g. Guterch et al., 1996; Grad et al., 2009). In case of the JMR group, the waves leaving the source propagated within the oceanic crust first and then went through the continental-type lithosphere. Therefore, 2-D modelling was necessary to account for the variability between the oceanic and continental lithosphere encountered along this transect (Fig. 7b). The continental part has a similar vertical distribution of velocity to 1-D models for other azimuths.

Figure 4 shows the seismic sections for the GTR area. Most of the events in this region occur down to $20 \mathrm{~km}$ depth and the epicentral distances for those events are from 1500 to $2300 \mathrm{~km}$ (Fig. 4b). There is a good fit between the data and the traveltimes refracted at the base of the mantle LVZ (red dashed line) at the depth of $220 \mathrm{~km}$. It is observed in the first arrivals up to $2100 \mathrm{~km}$. The $P_{335} P$ (blue line) occurs as secondary arrivals. At an epicentral distance of about $2100 \mathrm{~km}$, there is an intersection of the traveltime branches of $P_{220}$ and $P_{440}$ (green dashed line) phases. After $2100 \mathrm{~km}$, the offset branch of $P_{440}$ (green dashed line) is observed in first arrivals.

Figure $4 \mathrm{c}$ shows the earthquakes from the focal depth range of $20-50 \mathrm{~km}$. These events were recorded at epicentral distances ranging from 1500 to $2300 \mathrm{~km}$. As in the previous group, the $P_{220}$ phase is observed in first arrivals at distances up to about $2100 \mathrm{~km}$. After $2100 \mathrm{~km}$ the $P_{440}$ phase arrives first. The $P_{335} P$ wave is also visible as a second group. $P_{440} P$ is also recorded in the form of high-amplitude signals observed at distances from 1950 to $2300 \mathrm{~km}$. The closer the distance of $2250 \mathrm{~km}$, the more difficult it is to separate $P_{335} P$ 


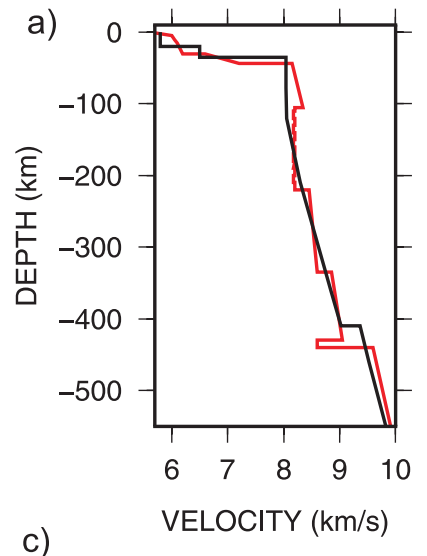

c)

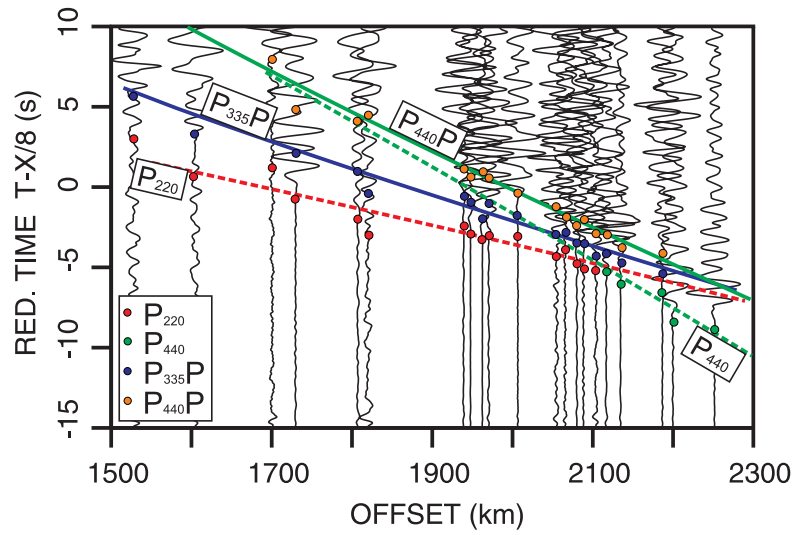

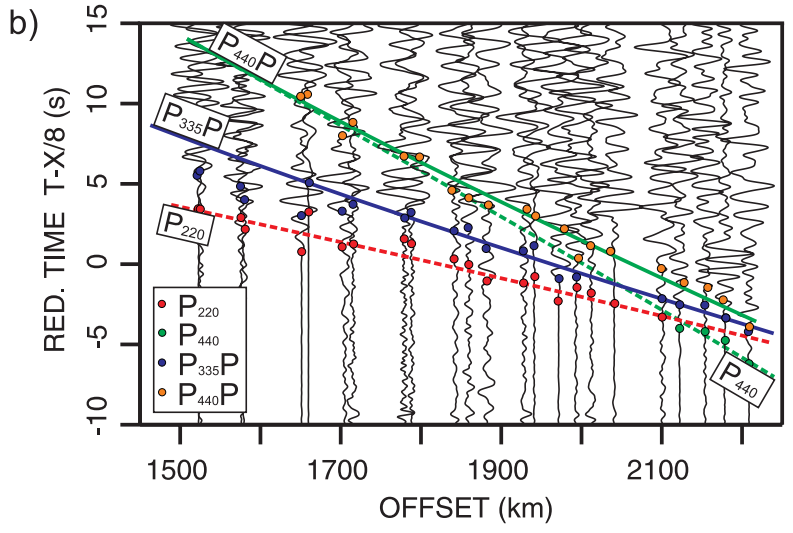

d)

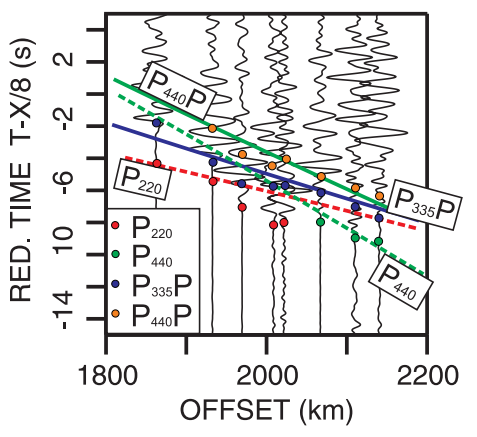

Figure 4. (a) The new MP1-SUW model (red line) compared with the AK 135 model (black line). (b-d) Seismic sections with traveltimes calculated for the MP1-SUW model for three focal depth ranges (b) 0-20 km, (c) 20-50 km, and (d) $>50 \mathrm{~km}$. Red dots represent $P_{200}$, green $-P_{440}$, blue $-P_{335} P$, and orange $-P_{440} P$ phases.

and $P_{440} P$ because these two branches intersect each other at this point.

Figure $4 \mathrm{~d}$ shows the deepest group of earthquakes (focal depth $>50 \mathrm{~km}$ ) recorded at the epicentral distances of 1860 to $2140 \mathrm{~km}$. $P_{220}$ can be seen only on two seismograms. Although, its presence at this depth is documented in the previous two sections. On this section the $P_{335} P$ and $P_{440} P$ reflected phases are also observed.

Figure 5 shows the seismic sections for the CR. Records from these events start at about 2000 and end at about $3000 \mathrm{~km}$ epicentral distance. Here we also divided data into three focal depth ranges: 0-20 km depth (Fig. 5a), 20-50 km depth (Fig. 5b) and $>50 \mathrm{~km}$ (Fig. 5c). In this case, we can only observe first arrivals of $P_{220}$ in the first two sections (red dashed line). However, analysis of the wavefield allows us to follow phases refracted from $440 \mathrm{~km}$ and reflected from 335 and $440 \mathrm{~km}$. On each section we have records documenting intersection of the two branches: $P_{335} P$ and $P_{440} P$ at $2250 \mathrm{~km}$, after which we observed $P_{440} P$ and then $P_{335} P$ as secondary arrivals.

In the case of the WMSR group of events, there is almost the whole range of the useful epicentral distances. The shallow focal depth range, $0-20 \mathrm{~km}$, allows us to put all events together in one seismic section (Fig. 6). Here we can observe $P_{220}$ as first arrivals at distances from 1700 to $2000 \mathrm{~km}$. At these distances we observe high-amplitude $P_{335} P$ and $P_{440} P$ as secondary arrivals. There is a lack of seismograms in the area where traveltime branches of $P_{220}$ and $P_{440}$ intersect, but after $2200 \mathrm{~km}$ we observe $P_{440}$ as first arrivals. Next we interpreted $P_{440} P$ phase followed by the $P_{335} P$ phase.

Figure 7a presents the seismic section for the JMR region. All those earthquakes are located along the rift zone close to the Jan Mayen Island in the northern Atlantic. Their focal depths are from 0 to $10 \mathrm{~km}$. The recorded epicentral distances ranging from 2260 to $2720 \mathrm{~km}$ allow us to model 335 and $440 \mathrm{~km}$ discontinuities. Taking into account differences in the oceanic and continental lithosphere, we build a 2-D velocity model. We observe $P_{440}$ as first arrivals and $P_{440} P$ as secondary arrivals. The $P_{335} P$ can be also distinguished in this seismic section. Figure $7 \mathrm{~b}$ illustrates ray-paths for reflection at $335 \mathrm{~km}$ depth and refraction and reflection at $440 \mathrm{~km}$ discontinuity.

Figure 8 presents all 249 earthquakes with focal-depth traveltime corrections applied in one seismic section. We added values consequent from different focal depths for each group respectively. These values were calculated during the 

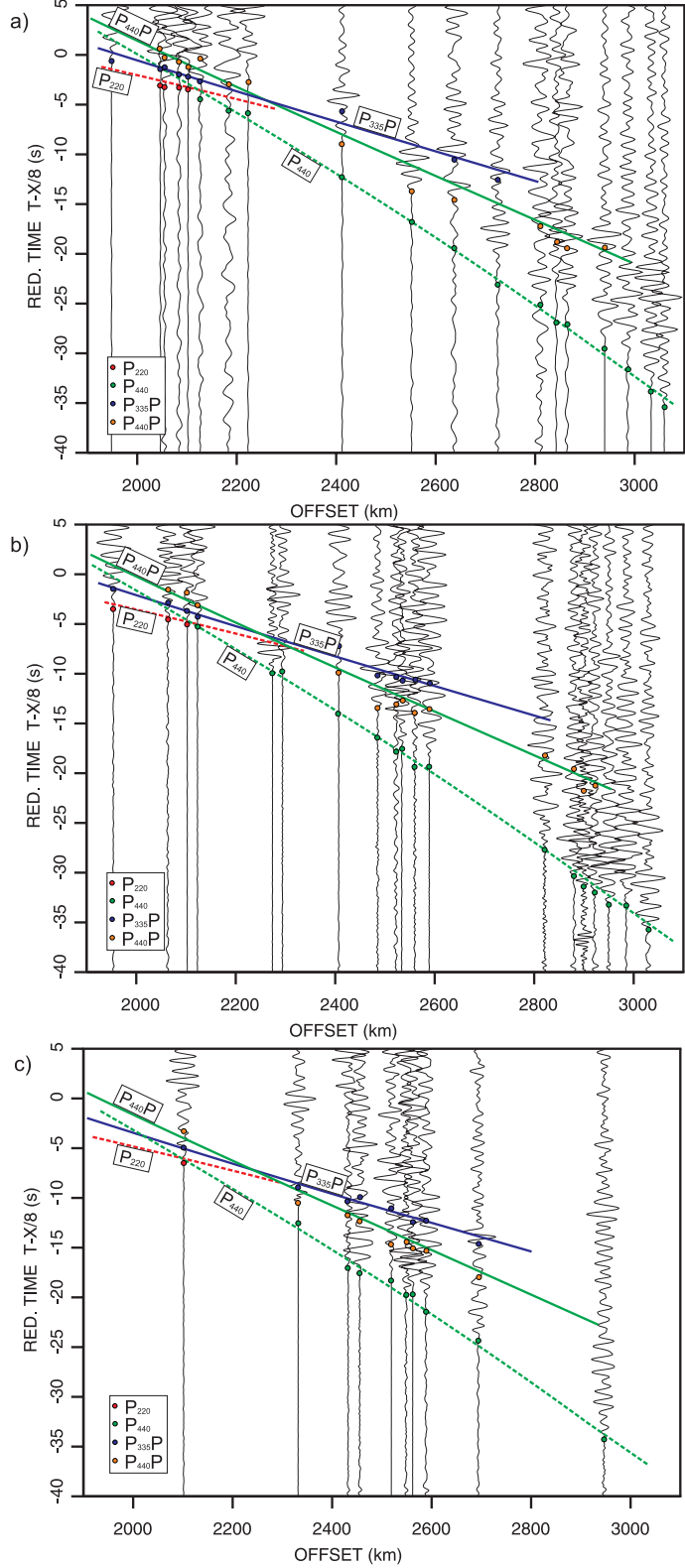

Figure 5. Seismic sections based on the data from the CR group with traveltimes calculated for the MP1-SUW model for three focal depth ranges (a) 0-20 km depth, (b) 20-50 km depth, and (c) $>50 \mathrm{~km}$. Red dots represent $P_{200}$, green $-P_{440}$, blue $-P_{335} P$, and orange $-P_{440} P$ phases.

separation of earthquakes into smaller groups. In order to verify the credibility of the derived models, we calculated synthetic seismograms using the reflectivity method (Fuchs and Muller, 1971; Muller, 1985). There is a good amplitude match between the recorded data (Fig. 8) and the synthetic section (Fig. 9).

There is an interesting feature in the MP1-SUW model presented here (Fig. 4a). Atop the $440 \mathrm{~km}$ discontinuity there is a $10 \mathrm{~km}$ thick zone with reduced velocities. The insertion

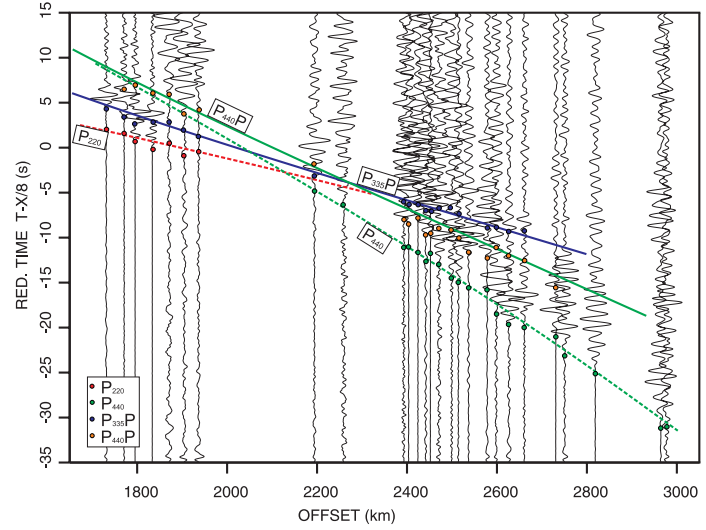

Figure 6. Seismic section based on data from the WMSR region with traveltimes calculated for the MP1-SUW model. Red dots represent $P_{200}$, green $-P_{440}$, blue $-P_{335} P$, and orange $-P_{440} P$ phases.

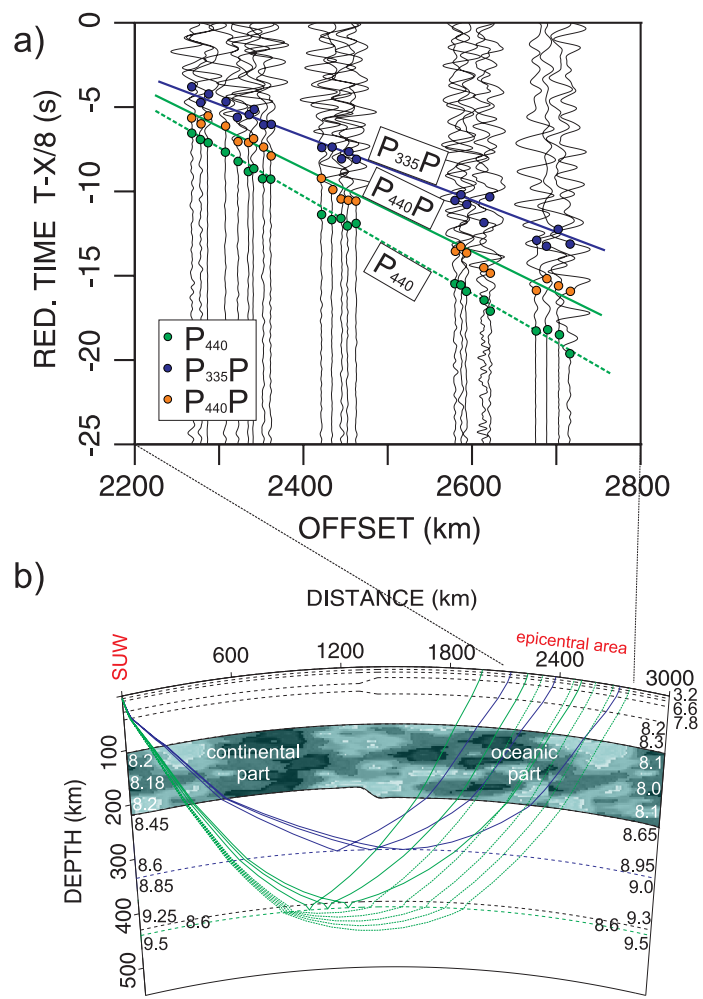

Figure 7. (a) Seismic section for the data from the JMR region with traveltimes calculated in the 2-D model shown in (b). (b) 2-D raytracing model and the ray paths refracted and reflected at 335 and $440 \mathrm{~km}$ discontinuities. Green dots represent $P_{440}$, orange $-P_{440} P$ phases, and blue $-P_{335} P$. Green pattern in the LVZ is used to represent heterogeneous nature of this layer modelled as thin low-highvelocity layers.

of the LVZ is necessary to explain the separation between $P_{440}$ and $P_{440} P$ branches as shown in Fig. 10. Figure 10a contains part of a section from Fig. 8 with the traveltimes 


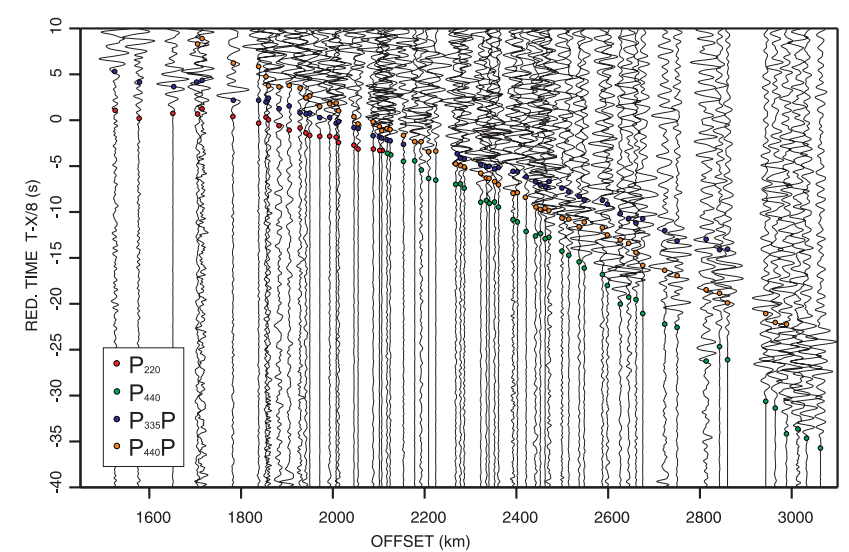

Figure 8. All analysed seismograms recorded at the SUW station with the focal depth corrections applied. Red dots represent $P_{200}$, green $-P_{440}$, blue $-P_{335} P$, and orange $-P_{440} P$ phases.

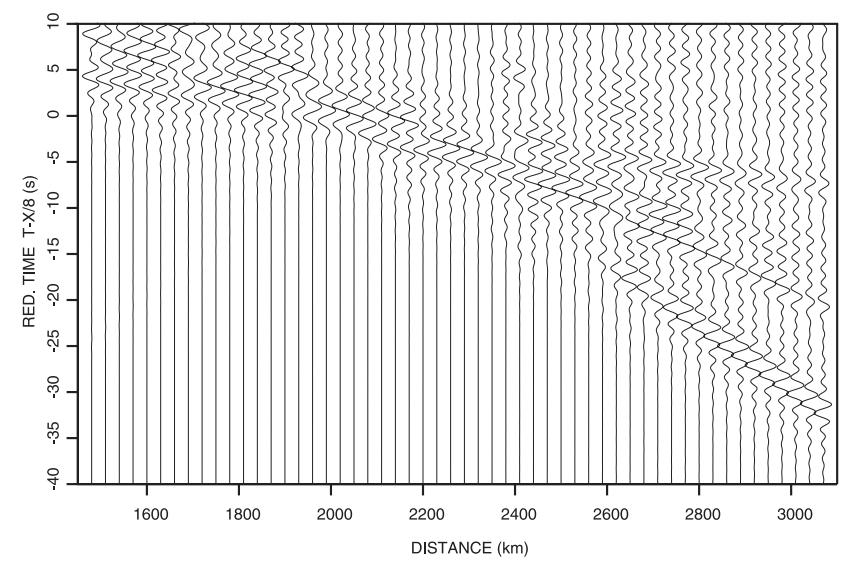

Figure 9. Synthetic seismograms section calculated for the MP1SUW model using the reflectivity method $(0.1-2.0 \mathrm{~Hz})$. Compare with data in Fig. 8.

calculated for the MP1-SUW model and Fig. 10b shows the same section with the traveltimes calculated for the model without the LVZ but with the same average velocity preserved.

\section{Error analysis}

We picked all the phases with the accuracy of $\pm 0.1 \mathrm{~s}$. The most significant uncertainties are attributed to the limited accuracy of the event location. The focal depth is the most uncertain hypocentre coordinate in the ISC bulletins, which were used in this analysis.

In order to demonstrate how well the predicted traveltimes fit to the observed data, we present histograms of traveltime residuals $\left(t_{\mathrm{obs}}-t_{\text {calc }}\right)$ in Fig. 11 . We compare the traveltime residuals of the first arrivals calculated for the MP1-SUW
Table 3. The MP1-SUW $P$ wave velocity model.

\begin{tabular}{lccc}
\hline $\begin{array}{l}\text { Depth } \\
(\mathrm{km})\end{array}$ & $\begin{array}{c}P \\
\text { wave }\end{array}$ & $\begin{array}{c}\text { Depth }(\mathrm{km}) \\
\text { velocity }\left(\mathrm{km} \mathrm{s}^{-1}\right)\end{array}$ & $\begin{array}{c}P \text { wave } \\
\text { velocity }\left(\mathrm{km} \mathrm{s}^{-1}\right)\end{array}$ \\
\hline 0 & 5.60 & 160 & 8.20 \\
5 & 6.00 & 170 & 8.20 \\
10 & 6.05 & 170 & 8.18 \\
15 & 6.10 & 180 & 8.18 \\
30 & 6.20 & 180 & 8.20 \\
30 & 6.60 & 190 & 8.18 \\
44 & 7.20 & 190 & 8.20 \\
44 & 8.15 & 200 & 8.20 \\
105 & 8.35 & 200 & 8.18 \\
105 & 8.20 & 210 & 8.18 \\
110 & 8.20 & 210 & 8.20 \\
110 & 8.18 & 220 & 8.20 \\
120 & 8.18 & 220 & 8.45 \\
120 & 8.20 & 335 & 8.60 \\
130 & 8.20 & 335 & 8.85 \\
130 & 8.18 & 430 & 9.05 \\
140 & 8.18 & 430 & 8.60 \\
140 & 8.20 & 440 & 8.60 \\
150 & 8.20 & 440 & 9.60 \\
150 & 8.18 & 620 & 10.10 \\
160 & 8.18 & & \\
\hline
\end{tabular}

model (Fig. 11a-e) and for the reference AK135 model (Kennett et al., 1995) (Fig. 11a'-e').

Figure 11a and 11a' show histograms for all earthquakes used. The adjustment for our model is better than for the AK135. There are smaller errors for the $-0.5-0.5 \mathrm{~s}$ range. The best fit was obtained for the Jan Mayen group of events (Fig. 11d). The traveltime residual range for that region is $\pm 1 \mathrm{~s}$. We attribute such a good fit to small focal depth uncertainties of the earthquakes from that region. Events with small focal differences are more unique. It could also be a result of the two-dimensional modelling.

The MP1-SUW model predicts two new branches of traveltimes for reflected waves, the $P_{335} P$ and $P_{440} P$. Figure 12 presents how they fit in the records collected at the SUW station. In the case of other models, such as PREM (Preliminary Reference Earth Model; Dziewoński and Anderson, 1981), IASPEI91 (International Association of Seismology and Physics of the Earth's Interior; Kennett and Engdahl, 1991), AK135 (Kennett et al., 1995) or iPREF (Cammarano and Romanowicz, 2008) there is no possibility to make such analysis because they do not reflect regional-scale inhomogeneities.

In Table 4 we summarized the three parameters of the fitting quality: the standard deviation, variance, kurtosis and root mean square for all groups of data. Kurtosis is a measure of the deviation from the normal distribution (the kurtosis of the normal distribution is 3 for the applied formula). Distributions that have higher variation than the normal 
a)

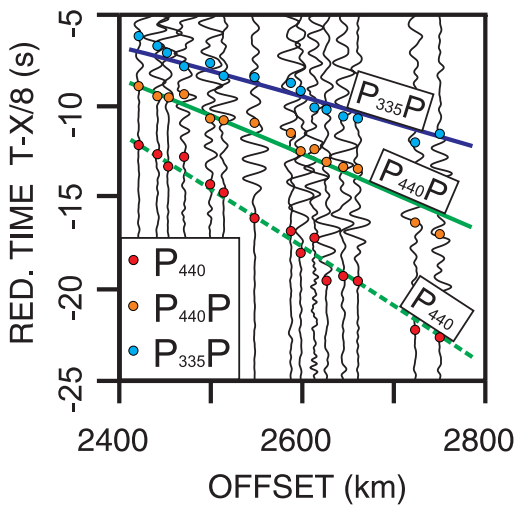

b)

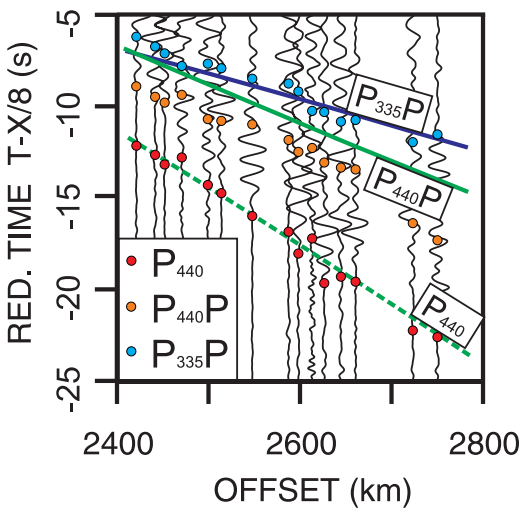

c)

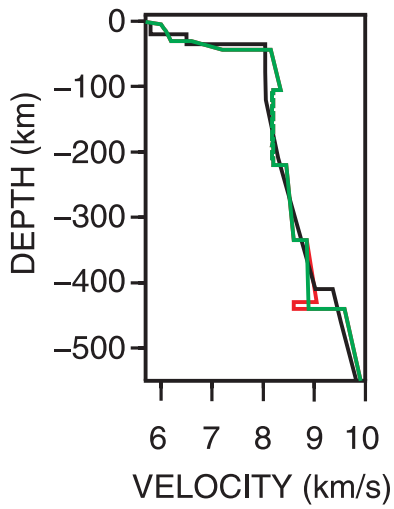

Figure 10. (a) Part of the seismic section with the MP1-SUW model traveltimes overlaid. Red dots represent $P_{440}$, orange $-P_{440} P$, and blue $-P_{335} P$. (b) Part of the seismic section with the traveltimes calculated for the model without the LVZ atop the $440 \mathrm{~km}$ discontinuity. (c) Comparison of 1-D seismic velocity models. Red line corresponds to the MP1-SUW model and green line to the same model without LVZ atop $440 \mathrm{~km}$ discontinuity. Black line corresponds to the AK135 model.

Table 4. Statistics of the traveltime residuals for the MP1-SUW (in bold) and the AK135 models (rms - root-mean square).

\begin{tabular}{|c|c|c|c|c|c|}
\hline Region & Number of events & Standard deviation & Variation & Kurtosis & RMS \\
\hline \multirow[t]{2}{*}{ Greece and Turkey region } & 103 & 1.01 & 1.01 & 4.46 & 1.00 \\
\hline & & 1.99 & 3.96 & 3.62 & 2.25 \\
\hline \multirow[t]{2}{*}{ Greece and Turkey 0-20 } & 53 & 0.85 & 0.73 & 3.32 & 0.88 \\
\hline & & 1.80 & 3.25 & 3.74 & 3.03 \\
\hline \multirow[t]{2}{*}{ Greece and Turkey 20-50 } & 36 & 1.10 & 1.22 & 6.18 & 1.10 \\
\hline & & 1.40 & 1.96 & 3.76 & 1.43 \\
\hline \multirow[t]{2}{*}{ Greece and Turkey 50+ } & 14 & 1.18 & 1.40 & 2.69 & 1.20 \\
\hline & & 1.29 & 1.65 & 2.76 & 1.44 \\
\hline \multirow[t]{2}{*}{ Caucasus region } & 69 & 1.50 & 2.26 & 3.45 & 1.46 \\
\hline & & 1.61 & 2.59 & 2.79 & 1.65 \\
\hline \multirow[t]{2}{*}{ Caucasus 0-20 } & 34 & 1.67 & 2.78 & 2.33 & 1.64 \\
\hline & & 1.86 & 3.44 & 2.21 & 1.87 \\
\hline \multirow[t]{2}{*}{ Caucasus 20-50 } & 23 & 1.58 & 2.51 & 4.38 & 1.55 \\
\hline & & 1.55 & 2.40 & 3.52 & 1.59 \\
\hline \multirow[t]{2}{*}{ Caucasus 50+ } & 12 & 0.77 & 0.60 & 3.08 & 0.74 \\
\hline & & 0.86 & 0.73 & 3.65 & 1.13 \\
\hline \multirow[t]{2}{*}{ Western Mediterranean Sea region } & 43 & 1.20 & 1.44 & 3.57 & 1.19 \\
\hline & & 1.57 & 2.46 & 2.15 & 1.63 \\
\hline \multirow[t]{2}{*}{ Jan Mayen region } & 34 & 0.32 & 0.10 & 2.22 & 0.36 \\
\hline & & 0.27 & 0.07 & 2.63 & 0.29 \\
\hline \multirow[t]{2}{*}{ All events } & 249 & 1.08 & 1.31 & 3.72 & 1.07 \\
\hline & & 1.58 & 2.79 & 3.00 & 1.71 \\
\hline $\mathbf{P}_{335} \mathbf{P}$ & 83 & 0.75 & 0.56 & 3.91 & 0.75 \\
\hline $\mathbf{P}_{440} \mathbf{P}$ & 76 & 0.75 & 0.57 & 4.00 & 0.80 \\
\hline
\end{tabular}

distribution have a kurtosis greater than 3 , distributions with lower variation have a kurtosis less than 3 .

The presented summary of the traveltime residuals' statistics shows the fitting parameters with respect to the MP1SUW model and the AK135 respectively. We subdivided GTR and CR analysis into smaller groups according to their focal depths. The calculated residuals are also smaller for the JMR. The comparison of the data in Table 4 shows that the experimental data is described better by our model than the global reference AK135 model. Although the AK135 model describes first arrivals well, it does not take into account reflected waves and regional discontinuities such as the $300 \mathrm{~km}$ discontinuity. 
a)

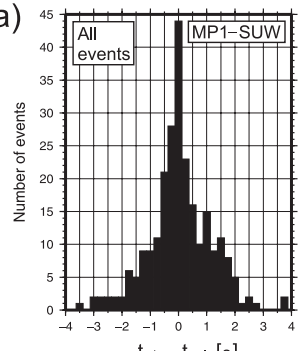

b)
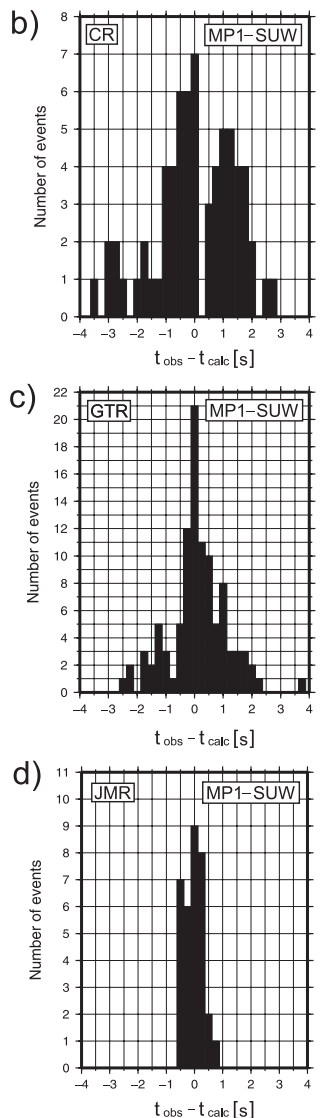

e)

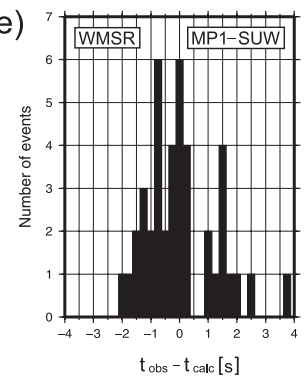

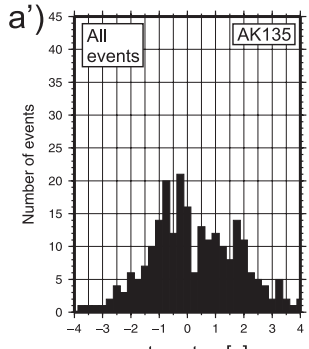

$t_{\text {obs }}-t_{\text {calc }}[s]$
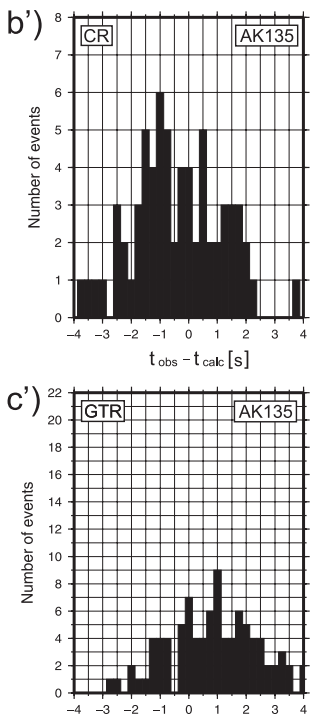

$t_{\text {obs }}-t_{\text {calc }}[s]$
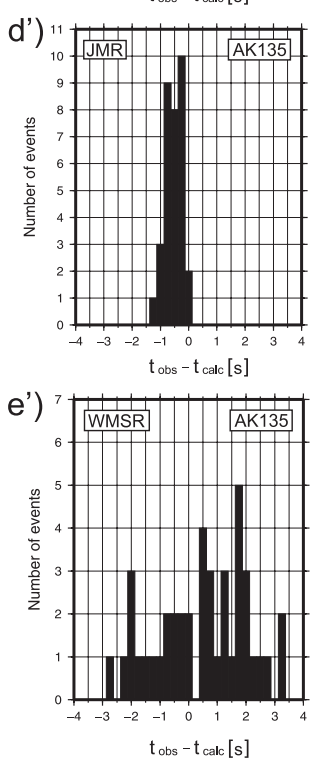

Figure 11. Histograms of the residuals between the observed traveltimes and the traveltimes calculated for the MP1-SUW model (left column) and between the observed traveltimes and the traveltimes calculated for the AK135 model (right column) for the following data: (a) (a') all events, (b) (b') events from the CR, (c) (c') events from the GTR , (d) (d') events from the JMR, (e) (e') events from the WMSR.
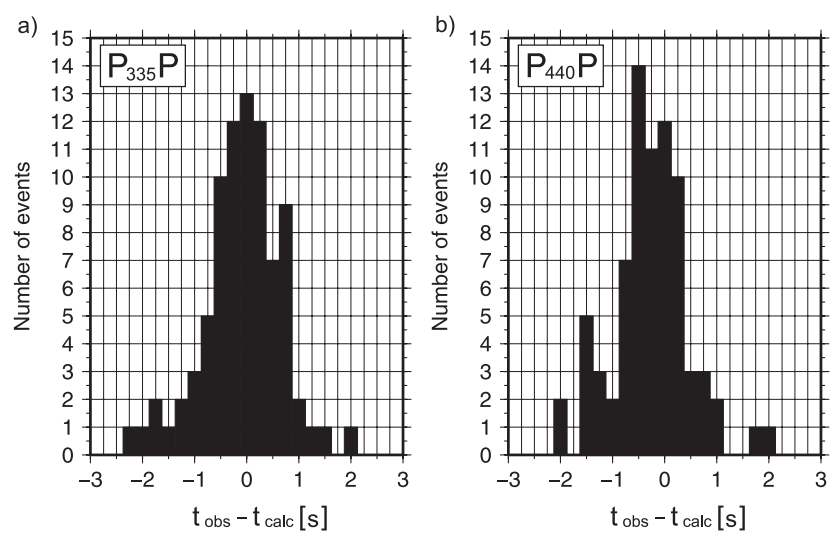

Figure 12. Histograms of the traveltime residuals between the reflected phases $P_{335} P$ (left column), the $P_{440} P$ ones (right column) and the calculated traveltimes for the MP1-SUW model.

Based on the analysis of both the refracted and reflected arrivals, we estimated uncertainty of the velocities in the MP1SUW model for each layer as $\pm 0.025 \mathrm{~km} \mathrm{~s}^{-1}$. The uncertainty for the depth of each discontinuity is $\pm 10 \mathrm{~km}$.

\section{Discussion}

The MP1-SUW model is intended to characterize upper mantle structure below the western rim of the EEC. Both 1-D and 2-D models provide a consistent image. The Lehmann $220 \mathrm{~km}$ phase, defining the bottom of the low-velocity zone (Lehmann, 1961), is seen as first arrivals for the distance range of $1500-2150 \mathrm{~km}$. A very prominent feature of the MP1-SUW model is the existence of the $300 \mathrm{~km}$ discontinuity at the depth of $335 \mathrm{~km}$, which is observed at the $1500-2800 \mathrm{~km}$ offset range. The origin of the $300 \mathrm{~km}$ discontinuity is generally related to the existence of a subduction zone (Revenaugh and Jordan, 1991), where increased amount of free silica is delivered to the upper mantle by subducted oceanic and continental material. Both coesitestishovite phase transformation and the thermal anomaly caused by a subducting slab can explain the velocity jump at this discontinuity (Liu et al., 1999). With relation to the mechanical mixture model of Xu et al. (2008), the jump in $P$ wave velocity at approximately $335 \mathrm{~km}$ depth would require enrichment in the basaltic component. In this region, the nature of this boundary can be tentatively explained as the traces of the ancient subduction regime related to the closure of the Iapetus and Rheic oceans and the Tornquist Sea (e.g. Torsvik et al., 1996, Torsvik and Rehnström, 2003). This discontinuity, due to its regional scale, is recorded better for the JMR and CR groups of events, although we observe it also for the WMSR and GTR groups. An independent support for the existence of such a discontinuity was recently provided by Knapmeyer-Endrun et al. (2013), who studied the $P$ wave receiver function based on the data from 
the PASSEQ experiment. There is a clear peak observed in the receiver function section clustered around TTZ at ca. $30 \mathrm{~s}$ relative time (see Fig. 7 in Knapmeyer-Endrun et al., 2013), which is roughly equivalent to ca. $300 \mathrm{~km}$ depth. However, authors do not comment whether this signal is related to primary or multiple energy.

We modelled $410 \mathrm{~km}$ discontinuity at the depth of $440 \mathrm{~km}$. It is observed as first arrivals in the $2150-3100 \mathrm{~km}$ offset range. The deeper location of this discontinuity compared to the reference global model (e.g. AK135) relates to the observation of the LVZ atop it. We find reports of such a zone in regional-scale investigations (Thybo et al., 1997). It was also postulated as the global phenomenon (Bercovici and Karato, 2003). In this case it can also be explained as an ancient oceanic structure subducted during the closure of the Tornquist Sea (Torsvik and Rehnström, 2003). We interpret the low-velocity zone above $410 \mathrm{~km}$ discontinuity as a result of the dehydration of the subducted plate that brought some residual water in the transition zone. This feature was found and documented also in the western part of the United States (Song et al., 2004), where authors interpreted it as a compositional anomaly. It could be caused by a dense partially melted layer linked to prior subduction of the Farallon Plate and back-arc extension.

Comparing MP1-SUW model with regional tomographic models based on $P$ wave traveltimes like the one of Koulakov et al. (2009), we observe similar pattern of the velocity anomalies in the regions analysed in this paper (Fig. 1b), both in horizontal and vertical slices. However the comparison is not straightforward as the tomographic models are inherently smooth and continuous whereas our model contain discontinuities modelled using reflected waves.

\section{Conclusions}

We derived a new $P$ wave velocity model of the upper mantle structure characterizing the western rim of the East European Craton (model MP1-SUW). Analysing seismic record sections from events recorded at the SUW station, we calculated a one-dimensional $P$ wave velocity model for the azimuthally differentiated regions: the Western Mediterranean Sea region, the Greece and Turkey region and the Caucasus region. The two-dimensional model for the JMR region was justified by the fact that waves propagating from that source region travel through the oceanic and continental structures.

The MP1-SUW model documents the bottom of the asthenospheric low-velocity zone at the depth of $220 \mathrm{~km}$, $335 \mathrm{~km}$ discontinuity and the zone with the reduction of $P$ wave velocity atop $410 \mathrm{~km}$ discontinuity which is depressed to $440 \mathrm{~km}$ depth. The nature of both the 335 and $440 \mathrm{~km}$ discontinuities are explained by tracing the ancient subduction regime related to the closure of the Iapetus and Rheic oceans and the Tornquist Sea (Torsvik and Rehnström, 2003). The $335 \mathrm{~km}$ discontinuity is a robust feature of the MP1-SUW model, however we are aware that this feature is not ubiquitous, but linked to the marginal zone of the EEC.

The work presented here shows that even a single station can be a rich source of information when a careful phase identification and modelling are implemented. We hope that the seismological community can benefit from the use of the MP1-SUW model in other regional studies, for example, in receiver function calculation or traveltime tomography.

\section{The Supplement related to this article is available online at doi:10.5194/se-5-523-2014-supplement.}

Acknowledgements. This study has been funded by the National Science Centre. Grant no. DEC-2011/01/N/ST10/07275. We are very grateful to Piotr Środa for fruitful discussions. Some of the figures were prepared using Generic Mapping Tool software (Wessel and Smith, 1995). We thank two anonymous reviewers and the editor for comments that helped us improve our paper.

Edited by: J. Plomerova

\section{References}

Abramovitz, T., Thybo, H., and MONA LISA Working Group: Seismic structure across the Caledonian deformation front along MONA LISA profile 1 in the southeastern North Sea, Tectonophys, 288, 153-176, 1998.

Abramovitz, T., Landes, M., Thybo, H., Jacob, A. W. B., and Prodehl, C.: Crustal velocity structure across the Tornquist and Iapetus Suture Zones - a comparison based on MONA LISA and VARNET data, Tectonophys, 314, 69-82, 1999.

Abramovitz, T., Thybo, H., and Perchuc, E.: Tomographic inversion of seismic $P$ and $S$ wave velocities from the Baltic Shield based on FENNOLORA data, Tectonophys, 358, 151-174, 2002.

BABEL Working Group: Evidence for early Proterozoic plate tectonics from seismic reflection profiles in the Baltic Shield, Nature, 348, 34-38, 1991.

BABEL Working Group: Deep seismic reflection/refraction interpretation of crustal structure along BABEL profiles A and B in the southern Baltic Sea, Geophys. J. Int., 112, 325-343, 1993.

Bastow, I. D.: Relative arrival-time upper-mantle tomography and the elusive background mean, Geophys. J. Int., 190, 1271-1278, 2012.

Bercovici, D. and Karato, S.: Whole-mantle convection and the transition-zone water filter, Nature, 425, 39-44, 2003.

Bock, G., Perchuc, E., Hanka, W., Wiejacz, P., Kind, R., Suchcicki, J., and Wylengalla, K.: Seismic anisotropy beneath the Suwalki station: one year of the activity of the station, Acta Geophys. Pol., 45, 1-12, 1997.

Bogdanova, S. V., Gorbatschev, R., and Stephenson, R. A.: EUROBRIDGE: paleoproterozoic accretion of Fennoscandia and Sarmatia, Tectonophys, 339, vii-x, 2001. 
Bogdanova, S. V., Gorbatschev, R., and Garetsky, R. G.: The East European craton, in: Encyclopedia of Geology, edited by: Selley, R. C., Cocks, L. R., and Plimer, I. R., Elsevier, 2, 34-49, 2005.

Cammarano, F. and Romanowicz, B.: Radial profiles of seismic attenuation in the upper mantle based on physical models, Geophys. J. Int., 175, 116-134, 2008.

Chu, R., Schmandt, B. and Helmberger D. V.: Upper mantle P velocity structure beneath the Midwestern United States derived from triplicated waveforms, Geochem. Geophys. Geosyst., 13, 1-21, 2012.

Cocks, L. R. M. and Torsvik, T. H.: European geography in a global context from the Vendian to the end of the Palaeozoic, in: European Lithosphere Dynamics, edited by: Gee, D. G. and Stephenson, R. A., Geological Society, London, Memoirs, 32, 83-95, 2006.

Dziewoński, A. and Anderson, D.: Preliminary reference Earth model, Phys. Earth Planet. In., 25, 297-356, 1981.

EUGENO-S Working Group: Crustal structure and tectonic evolution of the transition between the Baltic Shield and the North German Caledonides (the EUGENO-S Project), Tectonophys, 150, 253-348, 1988.

EUROBRIDGE Seismic Working Group: Seismic velocity structure across the Fennoscandia-Sarmatia suture of the East European craton beneath the EUROBRIDGE profile through Lithuania and Belarus, Tectonophys, 314, 193-217, 1999.

Fuchs, K. and Müller, G.: Computation of synthetic seismograms with the reflectivity method and comparison with observations, Geophys. J. Roy. Astr. S., 23, 417-433, 1971.

Gee, D. G.: Tectonic model for central part of scandinavian caledonides, Am. J. of Sci., A275, 468-515, 1975.

Gorman, A. R.: Ray-theoretical seismic traveltime inversion - modifications for a two-dimensional radially parametrized Earth, Geophys. J. Int., 151, 511-516, 2002.

Grad, M., Keller, G. R., Thybo, H., Guterch, A., and POLONAISE Working Group: Lower lithospheric structure beneath the TransEuropean Suture Zone from POLONAISE'97 seismic profiles, Tectonophys, 360, 153-168, 2002.

Grad, M., Tiira, T., and ESC Working Group: The Moho depth map of the European Plate, Geophys. J. Int., 176, 279-292, 2009.

Gregersen, S., Voss, P., Nielsen, L. V., Achauer, U., Busche, H., Rabbel, W., and Shomali, Z. H.: Uniqueness of modeling results from teleseismic $P$ wave tomography in Project Tor, Tectonophys, 481, 99-107, 2010.

Guggisberg, B. and Berthelsen, A.: A two-dimensional velocity model for the lithosphere beneath the Baltic Scield and its possible tectonic significance, Terra Cognita, 7, 631-638, 1987.

Guterch, A., Grad, M., Materzok, R., Perchuc, E., and Toporkiewicz, S.: Results of seismic crustal studies in Poland, Publ. Inst. Geophys. Pol. Acad. Sci., 17, 84-89, 1986.

Guterch, A., Grad, M., Materzok, R., and Perchuc, E.: Deep structure of the Earth's crust in the contact zone of the Paleozoic and Precambrian Platforms in Poland (Tornquist-Teisseyre zone), Tectonophys, 128, 251-279, 1996.

Guterch, A., Grad, M., Thybo, H., Keller, G. R., and POLONAISE Working Group: POLONAISE'97 - international seismic experiment between Precambrian and Variscan Europe in Poland, Tectonophys, 314, 101-121, 1999.
Guterch, A., Grad, M., and Keller, G. R.: Seismologists celebrate the new Millennium with an experiment in Central Europe, EOS Trans. AGU, 82, 529, 534-535, 2001.

Guterch, A., Wybraniec, S., Grad, M., Chadwick, R. A., Krawczyk, C. M., Ziegler, P. A., Thybo, H., and Vos, W. D.: Crustal structure and structural framework, in: Petroleum Geological Atlas of the Southern Permian Basin Area, edited by: Doornenbal, J. C. and Stevenson, A. G., EAGE Publications B. V., 11-23, 2010.

Hoffman, P. F.: United Plates of America, the birth of a craton: early proterozoic assembly and growth of Laurentia, Annu. Rev. Earth Pl. Sc., 16, 543-603, 1988.

ISC Bulletin, available at: http://www.isc.ac.uk/iscbulletin (last access: May 2013), 2013.

Kamiński, W. and Müller, G.: Program LAUFZEIT, University of Karlsruhe, 1979.

Kennett, B. L. N. and Engdahl, E. R.: Travel times for global earthquake location and phase identification, Geophys. J. Int., 105, 429-465, 1991.

Kennett, B. L. N., Engdahl, E. R., and Buland, R.: Constraints on seismic velocities in the earth from travel times, Geophys. J. Int, 122, 108-124, 1995.

Knapmeyer-Endrun, B., Krüger, F., Legendre, C., Geissler, W., and PASSEQ Working Group: Tracing the influence of the TransEuropean Suture Zone into the mantle transition zone, Earth Planet. Sc. Lett., Elsevier, 363, 73-87, 2013.

Koulakov, I., Kaban, M. K., Tesauro M., and Cloetingh S.: $P$ - and $S$-velocity anomalies in the upper mantle beneath Europe from tomographic inversion of ISC data, Geophys. J. Int., 179, 345366, 2009.

Liu, J., Zhang, J., Flesch, L., Li, B., Weidner, D., and Liebermann, R.: Thermal equation of state of stishovite, Phys. Earth Planet. In., 112, 257-266, 1999.

Lehmann, I.: S and the Structure of the Upper Mantle, Geophys. J. Roy. Astr. S., 4, 124-138, 1961.

Levander, A.: USArray design implications for wavefield imaging in the lithosphere and upper mantle, The Leading Edge, 22, 250255, 2003.

Müller, G.: The reflectivity method: a tutorial, J. Geophys., 58, 153174, 1985.

Nita, B., Dobrzhinetskaya, L., Maguire, P., and Perchuc, E.: Age-differentiated subduction regime: An explanation of regional scale upper mantle differences beneath the Alps and the Variscides of Central Europe, Phys. Earth Planet. In., 206-207, $1-1,2012$.

Perchuc, E. and Thybo, H.: A new model of upper mantle $P$ waves velocity below the Baltic Shield, Indication of partial melt in the 95 to $160 \mathrm{~km}$ depth range, Tectonophys, 253, 227-245, 1996.

Perchuc, E., Malinowski, M., and Nita, B.: Seismic and petrological properties of the upper mantle between 300 and $400 \mathrm{~km}$ depth, AGU Fall Meeting, S14C-01, 2008.

Plomerová, J., Babuška, V., Vecsey, L., and Kouba, D.: Seismic anisotropy of the lithosphere around the Trans-European Suture Zone (TESZ) based on teleseismic body-wave data of the TOR experiment, Tectonophys, 360, 89-114, 2002.

Revenaugh, J. and Jordan, T.: Mantle layering from ScS reverberations: the upper mantle, J. Geophys. Res., 96, 19781-19810, 1991. 
Shapiro, N. M. and Ritzwoller, M. H.: Monte-Carlo inversion for a global shear velocity model of the crust and upper mantle, Geophys. J. Int., 151, 1-18, 2002.

Song, T. A., Helmberger, D. V., and Grand, S. P.: Low-velocity zone atop the $410 \mathrm{~km}$ seismic discontinuity, Nature, 427, 530 533, 2004.

Somali, Z. H., Roberts, R. G., Pedersen, L. B., and the TOR Working Group: Lithospheric structure of the Tornquist Zone resolved by nonlinear $\mathrm{P}$ and $\mathrm{S}$ teleseismic tomography along the TOR array, Tectonophys, 416, 133-149, 2006.

Świeczak, M., Grad, M., and TOR and SVEKALAPKO Working Groups: upper mantle seismic discontinuities: topography variations beneath Eastern Europe, Acta Geophys. Pol., 52, 251-270, 2004.

Thybo, H. and Perchuc, E.: The seismic $8^{\circ}$ discontinuity and partial melting in continental mantle, Science, 275, 1626-1629, 1997.

Thybo, H., Perchuc, E., and Pavlenkova, N.: Two Reflectors in the $400 \mathrm{~km}$ Depth Range Revealed from Peaceful Nuclear Explosion Seismic Sections, Upper Mantle Heterogeneities from Active and Passive Seismology, edited by: Fuchs, K., NATO ASI Series, 97104, 1997.

Torsvik, T. H., Smethurst, M. A., Meert, J. G., Van der Voo, R., McKerrow, W. S., Brasier, M. D., Sturt, B. A., and Walderhaug. H. J.: Continental break-up and collision in the Neoproterozoic and Palaeozoic: a tale of Baltica and Laurentia, EarthSci. Rev., 40, 229-258, 1996.

Torsvik, T. H. and Rehnström, E. F.: The Tornquist Sea and BalticaAvalonia docking, Tectonophys, 362, 67-82, 2003.
Wessel, P. and Smith, W. H. F.: New version of Generic Mapping Tools released, EOS, 76, 453, 1995.

Wilde-Piórko, M.: Crustal structure from seismic receiver function, Przegląd Geofizyczny, 1-2, 31-45, 2005.

Wilde-Piórko, M., Geissler, W., Plomerová, J., Grad, M., Babuška, V., Brückl, E., Cyziene, J., Czuba, W., England, R., Gaczyński, E., Gazdova, R., Gregersen, S., Guterch, A., Hanka, W., Hegedûs, E., Heuer, B., Jedlička, P., Lazauskiene, J., Keller, G., Kind, R., Klinge, K., Kolinsky, P., Komminaho, K., Kozlovskaya, E., Krüger, F., Larsen, T., Majdański, M., Malek, J., Motuza, G., Novotný, O., Pietrasiak, R., Plenefisch, T., Růžek, B., Sliaupa, S., Środa, P., Świeczak, M., Tiira, T., Voss, P., and Wiejacz, P.: PASSEQ 2006-2008: Passive seismic experiment in Trans-European Suture Zone, Studia Geophysica et Geodetica, 52, 439-448, 2008.

Xu, W., Lithgow-Bertelloni, C., Stixrude, L., and Ritsema, J.: The effect of bulk composition and temperature on mantle seismic structure, Earth Planet. Sci. Lett., 275, 70-79, 2008.

Zelt, C.: ZPLOT - an iteractive plotting and picking program for seismic data, Bullard Lab. Univ. of Cambridge, Cambridge UK, 1994.

Ziegler, P. A. and Dèzes, P.: Crustal configuration of Western and Central Europe, in: European Lithosphere Dynamics, edited by: Gee, D. G. and Stephenson, R. A., Geol. Soc., London, Memoirs 32, 43-56, 2006.

Znosko, J.: Polish Caledonides and their relation to other European Caledonides, Ann. Soc. Geol. Pol., 56, 33-52, 1986. 